\title{
Obogaćeni jezični unos - intervencija u potpomognutoj komunikaciji temeljena na modeliranju
}

\author{
Klara Popčević, Jasmina Ivšac Pavliša, Ana Marija Bohaček \\ Edukacijsko-rehabilitacijski fakultet Sveučilišta u Zagrebu, Zagreb, Hrvatska
}

Sažetak: Područje intervencija u kontekstu potpomognute komunikacije koje kao temeljeni princip upotrebljavaju modeliranje istraživačko je područje koje se intenzivnije razvija posljednjih nekoliko godina. Unatoč brojnim pokazateljima da je strategija modeliranja jezičnog unosa svrhovita za jezični razvoj, modeliranje se u kliničkom radu tradicionalno povezuje s modeliranjem gesti, manualnih znakova i govornih oblika, a puno rjeđe u kontekstu modeliranja uporabe grafičkih simbola, komunikacijskih ploča, knjiga ili visokotehnoloških uređaja paralelno s govorom. Intervencije potpomognute komunikacije koje uključuju modeliranje (engl. AAC modeling interventions) usmjerene su na poticanje jezičnih sposobnosti djece koja upotrebljavaju potpomognutu komunikaciju. U radu će se obrazložiti teorijsko ishodište koncepta obogaćenog jezičnog unosa koji je zapravo strategija "receptivnog jezičnog treninga". U okviru ove strategije ključna je uloga komunikacijskog partnera koji istodobno govori i pokazuje na grafičke simbole. Obogaćeni jezični unos ima svoje uporište u konstruktivističkim i socio-interakcionističkim teorijama jezičnog razvoja te u svojoj izvedbi upravo oponaša način na koji djeca tipičnoga razvoja usvajaju jezik. Pregled literature pokazuje da postoje brojni dokazi o učinkovitosti primjene obogaćenog jezičnog unosa u području komunikacijskog i jezičnog razvoja (Dada i Alant, 2009; Drager, 2009; Sennott, Light i McNaughton, 2016). Pregledni rad donosi ključne podatke o konceptu obogaćenog jezičnog unosa, terminološkom razvoju, istraživanjima i kliničke preporuke s ciljem približavanja ovog koncepta kako u istraživačkom, tako i u kliničkom radu.

Ključne riječi: modeliranje, potpomognuti jezik, komunikacijski partner, receptivni trening, potpomognuta komunikacija

\section{UVOD}

Jedan od početnih koraka u intervencijama koje su usmjerene na osobe koje ne upotrebljavaju govor kao primarno komunikacijsko sredstvo, odnosi se na pružanje potpomo- gnutog načina komunikacije izrađivanjem ili nabavljanjem komunikacijskih pomagala tim osobama. Međutim, naučiti kako komunicirati tim komunikacijskim pomagalima i pri tome 
usvojiti jezični sustav jest proces koji se ne podrazumijeva samim njegovim posjedovanjem, već zahtijeva pružanje podrške kako samim korisnicima, tako i njihovim komunikacijskim partnerima. U okviru suvremenih intervencijskih pristupa u okviru potpomognute komunikacije $(\mathrm{PK})$ ističe se onaj koji naglašava važnu ulogu modeliranja u tom procesu. Modeliranje je strategija koja se intuitivno koristi kao podrška tipičnom jezičnom razvoju, ali i u okviru podrške kod različitih odstupanja i poremećaja u području komunikacije i jezika. Kao ključno obilježje u ovom se radu naglašava interaktivno modeliranje PK sustava od strane komunikacijskih partnera na način da usporedno s govorom pokazuju na simbole komunikacijskog sustava PK korisnika u kontekstu prirodnih komunikacijskih interakcija. Zbog obilježja jezičnog unosa koji se na taj način osigurava, ove intervencije često se opisuju terminom obogaćeni jezični unos. Ovaj rad opisuje podlogu te intervencije uspoređujući je s podlogom usvajanja jezika djece tipičnog razvoja, daje pregled glavnih značajki ove intervencije, njezinih učinaka i razvoja u okviru različitih intervencijskih pristupa i pod različitim nazivljem te završava kliničkim implikacijama, postojećim ograničenjima i istraživačkim preporukama. Potrebu za upoznavanjem i implementiranjem ove intervencije važno je naglasiti jer je ona nedovoljno zastupljena $\mathrm{u}$ logopedskoj i edukacijsko-rehabilitacijskoj praksi u Hrvatskoj, dok u istraživačkim inicijativama postupno dobiva svoj prostor (Ivšac Pavliša, Ljubešić i Jerečić, 2012; Kuhar, Prizl Jakovac i Ivšac Pavliša 2016; Rašan, Slivar, Žilak, Car i Ivšac Pavliša, 2019; Ivšac Pavliša, Popčević i Rosandić, 2019).

\section{Usvajanje jezika i govora u djece tipična razvoja}

Pojava prvih djetetovih riječi jedan je od najvažnijih ranih razvojnih pokazatelja koja je uoči djetetove prve godine u središtu pozornosti cijele njegove okoline. Iako se pojava govora događa naizgled spontano, ona se može dogoditi tek uz određene uvjete. Jedna od glavnih pretpostavki da dijete "progovori”, odnosno da upotrebljava i proizvodi jezik putem govora jest da ono bude okruženo tim istim jezikom, odnosno da sluša i razumije govoreni jezik drugih. Dijete tijekom prve godine odrasta slušajući i upijajući jezik svoje okoline koji postupno počinje razumijevati, a tek oko prve godine života samostalno počinje proizvoditi jezik putem govora. Hart i Risley (1995) izvještavaju kako djeca tipičnog razvoja imaju prilike čuti između 620 i 2150 riječi u sat vremena. Ovakvi podaci ističu važnost jezičnog unosa (engl. input) kao temelja jezičnog izlaza (engl. output), ulogu okoline koja pruža taj unos te količinu unosa kojom je dijete okruženo. Modalitet tog unosa (govor) jednak je modalitetu izlaza. Pojedini teoretičari ističu kako za usvajanja jezika nije dovoljno samo izlaganje jeziku, već i socijalne interakcije djece s odraslima i drugom djecom koja imaju bolje jezične sposobnosti od njih (Bruner, 1983; Vygotsky, 1962; Bohaček, 2020). Odrasli uključuju djecu u brojne interakcije koje služe kao podrška i temelj za usvajanje jezika, a potom i razvoj govora. Prema konstruktivističkim i socio-interakcionističkim teorijama usvajanja jezika, djeca uče riječi i gramatička pravila jezika tako što slušaju (ili vide) jezik kojim su okružena, ali isto tako komunicirajući i koristeći jezik za različite svrhe i u različitim kontekstima (Tomasello, 2003).

\section{Modaliteti komunikacije i uporabe jezika}

Opisani procesi i uvjeti usvajanja jezika $\mathrm{u}$ djece tipičnog razvoja usko su povezani s razvojem govora jer se jezik kao simboličko sredstvo prijenosa poruke najčešće ostvaruje 
Popčević, K., Ivšac Pavliša, J., Bohaček, A., Obogaćeni jezični unos - intervencija u potpomognutoj komunikaciji, Klinička psihologija 13 (2020), 1-2, 79-94

akustički, odnosno govorom. Iako je u tipičnom obrascu razvoja govor primarno komunikacijsko i jezično sredstvo, on nije jedino komunikacijsko sredstvo ni jedino simboličko, odnosno jezično sredstvo. Uz govor, komunikacija je moguća i facijalnom ekspresijom, gestama, vokalizacijama. Uz govoreni jezik, osobe koje su ovladale vještinama čitanja i pisanja komuniciraju i pisanim jezikom, a osobe koje imaju oštećenje sluha komuniciraju znakovima, odnosno znakovnim jezikom. Jezik se dakle može ostvariti putem govora, pisma, manualnih znakova, no manje je poznato da se jezik može ostvariti i putem grafičkih simbola. Takav jezik koji se ostvaruje u svrhe komunikacije putem grafičkih simbola u literaturi se naziva potpomognutim jezikom (engl. aided language) (von Tetzchner, 2018) ili vizualnim jezikom (engl. visual language) (Shane i sur., 2015).

\section{Korisnici potpomognute komunikacije i potpomognutog jezika}

Potpomognutim jezikom komuniciraju osobe sa složenim komunikacijskim potrebama (Beukelman i Mirenda, 2013), odnosno osobe koje koriste potpomognutu komuni- kaciju (PK) (von Tetzchner, 2018). One zbog različitih teškoća poput poremećaja iz spektra autizma, cerebralne paralize, intelektualnih teškoća i drugih razvojnih teškoća jezik ne mogu realizirati na uobičajeni način, odnosno govorom. Dio spomenutih osoba ne razvije govor uopće, dio govori vrlo ograničen broj riječi, dio govori komunikacijski nesvrhovito, a dio govori vrlo nerazumljivo. Te osobe imaju mogućnost komunicirati potpomognutom komunikacijom, što znači da mogu komunicirati uz različite strategije i tehnike skupom različitih sredstava (vokalizacijom, dodirom, gestama, manualnim znakovima, pismom, slikama, grafičkim simbolima) i komunikacijskih pomagala (pločama, knjigama i elektroničkim uređajima s vizualnim zaslonima i/ili govornim izlazom) (Beukelman i Mirenda, 2013; Burkhart, 2019). Komunikacijska pomagala sadrže grafičke komunikacijske sustave koji se sastoje od skupa lingvističkih grafičkih simbola, odnosno grafičkih slika s pridodanim pisanim tekstom, odnosno pisanim natpisima (engl. glosses) (Pampoulou, 2017) kao što je prikazano na Slici 1. Tako osobe koje zbog nedostatka kapaciteta za proizvodnju oralnog govorenog jezika komuniciraju potpomognutim jezikom, odnosno simbolima osmišljenima u svrhu slaganja rečenica u socijalnim in-

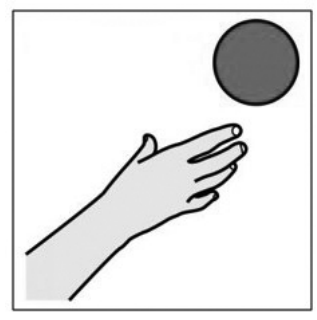

ŽELIM

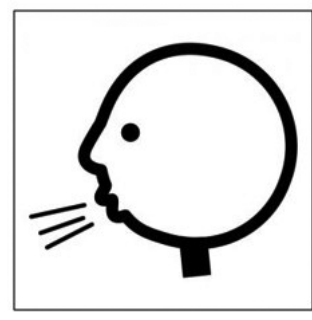

PUHATI

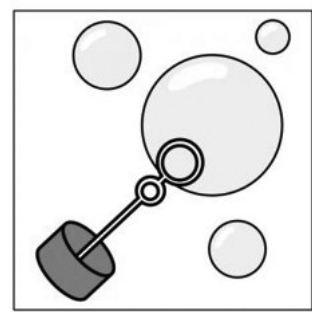

BALONČIĆE

Slika 1. Primjer lingvističkih grafičkih simbola u potpomognutom jeziku (Korišteni su grafički simboli nekomercijalne galerije ARASAAC) 
terakcijama i ispunjavanja svih ili gotovo svih funkcija govorenog jezika (von Tetzchner i Martinsen, 2000; von Tetzchner 2018).

\section{Temeljni rizici za jezični razvoj kod korisnika potpomognute komunikacije}

Usvajanje potpomognutog jezika izazov je djeci koja koriste PK jer se njihova rana iskustva koja su neophodna za usvajanje jezika značajno razlikuju od iskustava kojima su okružena djeca koja usvajaju govoreni jezik. Nepovoljna iskustva kojima su izložena podrazumijevaju nedostatnu uporabu PK sustava od strane njihovih komunikacijskih partnera te oskudan broj prilika u kojima sami korisnici PK komuniciraju svojim sustavom.

$\mathrm{Za}$ razliku od djece koja govore, djeca sa složenim komunikacijskim potrebama rijetko imaju priliku promatrati druge kako upotrebljavaju njihov komunikacijski sustav (Blockberger i Sutton, 2003; Romski i Sevcik, 1996), odnosno kako modeliraju upotrebu potpomognutog jezika. Primarni modalitet jezičnog unosa koji se najčešće pruža osobama koje koriste PK jest govoreni jezik (Light, 1997). U tim slučajevima jezični unos njihova okruženja razlikuje se u modalitetu od jezičnog izlaza, odnosno jezičnog PK sustava koji oni upotrebljavaju u proizvodnji. Dok su djeca koja upotrebljavaju PK okružena govorenim jezikom, od njih se očekuje da upotrebljavaju potpomognuti jezik, odnosno grafičke simbole. Na taj način stvara se asimetrija između modaliteta unosa i izlaza (Light, 1997; Smith i Grove, 2003). Nedostatak uporabe potpomognutog jezika od strane okoline dovodi do teškoća njegova razumijevanja od strane PK korisnika, a posljedično tome i u njegovoj proizvodnji. Ako okolina ne modelira uporabu simbola, dijete nema dovoljan broj prilika za usvojiti razumijevanje značenja grafičkih simbola koji predstavljaju određene lingvističke elemente (imenice, glagole, pridjeve i tako dalje) te usvojiti pravila njihova kombiniranja u niz sintaktički i semantički povezanih elemenata (Shane i sur., 2015). U posebnom su riziku djeca koja upotrebljavaju PK, a istodobno imaju teškoće razumijevanja jezika jer se u učenju značenja grafičkih komunikacijskih simbola, tj. u uspostavljanju veza između simbola i njihovih referenata ne mogu osloniti na postojeća receptivna jezična znanja (Romski i Sevcik, 1988).

Druga razlika u ranim iskustvima djece koja upotrebljavaju PK u odnosu na djecu koja govore jest manjak prilika za sudjelovanje u interakcijama u kojima mogu upotrebljavati svoj komunikacijski sustav s drugima (Calculator, 1997; Popčević, Ivšac Pavliša i Šimleša, 2014).

\section{Ključne postavke intervencija u kontekstu potpomognute komunikacije koje se temelje na modeliranju}

Narušenost ranih iskustava djece koja upotrebljavaju PK ima ozbiljne negativne implikacije za razvoj važnih ranih komunikacijskih i jezičnih vještina. Zbog toga je djeci sa složenim komunikacijskim potrebama uz sam pristup nekom od oblika potpomognute komunikacije potrebno osigurati i podršku u jezičnom razvoju (Solomon-Rice i Soto, 2014). U tu su svrhu osmišljene intervencijske tehnike kojima se potiču jezične sposobnosti djece koja počinju upotrebljavati PK, a zajedničkim imenom nazivaju se intervencije potpomognute komunikacije koje uključuju modeliranje (engl. AAC modeling interventions). One se temelje na konstruktivističkim i socio-interakcionističkim teorijama jezičnog razvoja te na naturalističkim intervencijskim pristupima (Tannock i Girolametto, 1992) koji naglaša- 
Popčević, K., Ivšac Pavliša, J., Bohaček, A., Obogaćeni jezični unos - intervencija u potpomognutoj komunikaciji, Klinička psihologija 13 (2020), 1-2, 79-94

vaju važnost jezičnog unosa i socijalnih interakcija u procesu usvajanja jezika (Gallway i Richards, 1994). Ove temeljne postavke imaju svoju potkrjepu kako u općoj lingvističkoj literaturi (Gerken, 2008), tako i u literaturi o znakovnim jezicima (Bavelier, Newport i Supalla, 2003).

Budući da djeca koja govore jačaju svoje sposobnosti jezičnog razumijevanja i proizvodnje upravo onih riječi koje su vrlo često bile upućene njima (Huttenlocher, Haight, Bryk, Seltzer i Lyons 1991), slični procesi vrlo vjerojatno pridonose razumijevanju i proizvodnji grafičkih simbola (Harris i Reichle, 2004). Kao i kod djece tipičnog razvoja koja usvajaju govoreni jezik ili kod djece koja usvajaju znakovni jezik, i kod djece koja usvajaju potpomognuti jezik važno je da budu "uronjena" u okruženje koje "govori njihovim jezikom”, u ovom slučaju okruženje koje "govori PK", odnosno upotrebljava njihov sustav potpomognute komunikacije. Takvo interaktivno modeliranje PK sustava od strane komunikacijskih partnera osigurava veću simetriju između jezičnog unosa i izlaza te čini temelj tehnika koje se pod različitim nazivima koriste $\mathrm{u}$ intervencijskim paketima potpomognute komunikacije.

\section{CILJ RADA}

$\mathrm{Na}$ temelju rezultata istraživanja razvoja jezika i govora u djece tipičnog razvoja te istraživanja o učinkovitosti potpomognute komunikacije i važnosti poučavanja jezika i svih jezičnih sastavnica u okviru potpomognute komunikacije (Wood, Lasker, Siegel-Causey, Beukelman i Ball, 1998), u ovom će se radu pojasniti razvoj i uloga strategije obogaćenog jezičnog unosa koja je relativno nepoznata $u$ istraživačkom i kliničkom prostoru u Hrvatskoj.

\section{Razvoj nazivlja i pojma obogaćeni jezični unos}

Tradicionalno, poučavanje PK više je bilo usmjereno na jezičnu proizvodnju osobe koja upotrebljava PK, dok se suvremeni pristupi u području PK usmjeravaju i na poticanje jezičnog razumijevanja i komunikacijskog procesa u cjelini te pri tome naglašavaju važnost jezičnog unosa. Obogaćeni jezični unos u PK opisuje se kao jedan od modela koji podupire jezično razumijevanje koristeći govor i specifično sredstvo PK kojim se služi korisnik (Smith i Grove, 2003; Sevick, Romski, Watkins i Deffebach, 1995). Iako ovaj koncept ima različite terminološke inačice, što je čest slučaj kod strategija ili intervencija koje su još uvijek u istraživačkom fokusu (Sevcik i Romski, 2002), u suvremenoj literaturi danas je uvriježena uporaba termina obogaćeni jezični unos.

Termin potpomognuti komunikacijski unos (engl. augmented communication input) prvi put su upotrebljavali Beukelman i Garrett (1988) predlažući da tijekom komunikacije s odraslim osobama sa složenim komunikacijskim potrebama komunikacijski partneri upotrebljavaju i PK sustave.

Sličan termin, obogaćeni jezični poticaj (engl. augmented language stimulation) autorice Goossens' (1989) odnosi se na pristup, odnosno vrstu receptivnog treninga u kojem komunikacijski partneri pokazuju na (ili aktiviraju) simbole na komunikacijskim sustavima tijekom uobičajenih komunikacijskih epizoda (Slika 2). Uz opisano modeliranje korisnik PK ima priliku upoznati koncept korištenja grafičkih simbola (Goossens', 1989). Na primjer, dijete pokaže na grafički simbol LJULJAČKA, a odrasla osoba kaže "Idemo na ljuljačku" i pokazuje pri tome grafičke simbole za IĆI i LJULJAČKA. Ako je dijete sa složenim komu- 


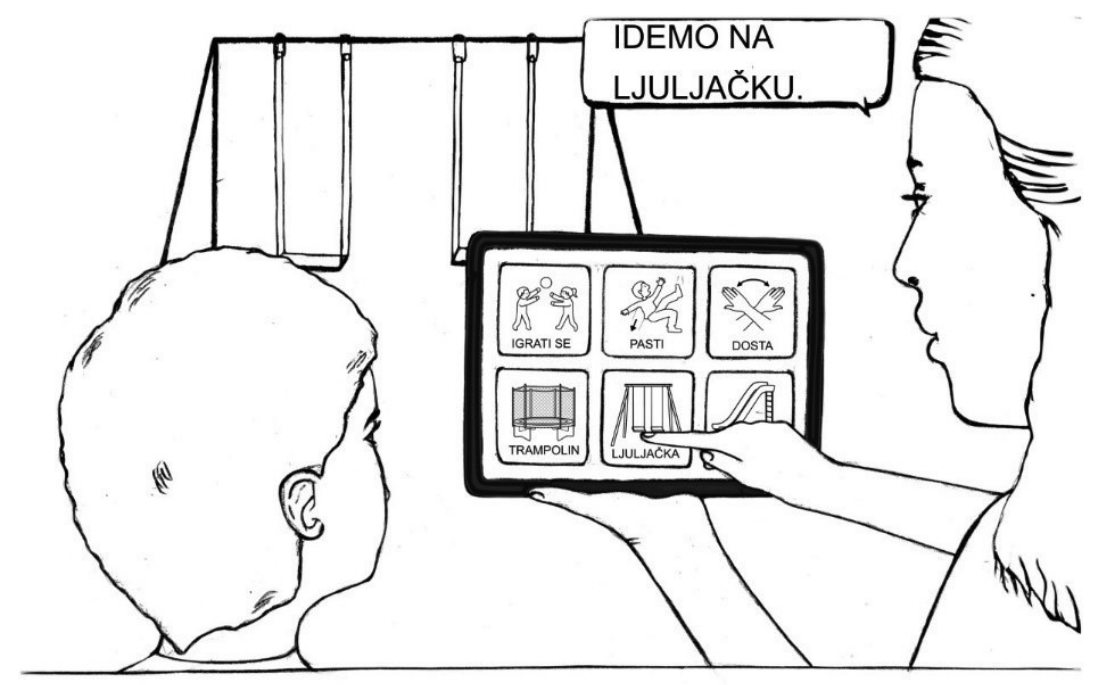

Slika 2. Primjer obogaćenog jezičnog unosa tijekom komunikacije na dječjem igralištu (Slika se koristi uz suglasnost autorice Anje Slovenc.)

nikacijskim potrebama poučavano na opisani način, nema potrebe za poučavanjem značenja svakog zasebnog simbola (Goossens', Crain i Elder, 1995). Iz navedenog, uočavaju se dva obilježja obogaćenog jezičnog unosa u PK povećanje jezičnog unosa te osiguravanje modela za napredak u rječničkom i jezičnom znanju.

Prepoznavanjem važnosti jezičnog unosa i jezičnog modela kod korisnika PK, razvijaju se intervencije u okviru kojih se zagovara i koristi model jezično obogaćenog unosa. Tablica 1 prikazuje nazivlje i opis intervencija te kronološki poredak njihova pojavljivanja u znanstvenoj i stručnoj literaturi.

Zajedničko navedenim intervencijama je da komunikacijski partner upotrebljava obo- gaćeni oblik PK, odnosno da uz govor pokazuje i/ili aktivira sredstvo PK koje inače upotrebljava dijete ili osoba sa složenim komunikacijskim potrebama.

Cijeli pristup u svojim temeljima sadrži principe usvajanja jezika djece tipičnog razvoja, stoga se u većini opisanih intervencija zagovara korištenje PK sustava u prirodnoj okolini, što strategiju obogaćenog jezičnog unosa postavlja u kontekst naturalističkih intervencija. Drugim riječima, korisnika PK poučava se korištenju sredstva komunikacije u rutinama, u njegovim svakodnevnim aktivnostima koje obiluju prilikama za uvježbavanje komunikacijskih vještina, pri čemu ključnu ulogu imaju komunikacijski partneri. 
Popčević, K., Ivšac Pavliša, J., Bohaček, A., Obogaćeni jezični unos - intervencija u potpomognutoj komunikaciji, Klinička psihologija 13 (2020), 1-2, 79-94

Tablica 1. Primjeri intervencija u okviru kojih se koristi obogaćeni jezični unos (prema O’ Neill, Light i Pope, 2018)

\begin{tabular}{|c|c|c|}
\hline Naziv intervencije & Opis intervencije na temelju opisa autora & Autori \\
\hline \multirow{4}{*}{$\begin{array}{l}\text { Obogaćeni jezični } \\
\text { poticaj } \\
\text { (engl. aided language } \\
\text { stimulation) }\end{array}$} & $\begin{array}{l}\text { Receptivni trening koji se provodi u dinamičkom, } \\
\text { interaktivnom formatu. }\end{array}$ & \multirow{4}{*}{$\begin{array}{l}\text { Goossens', } \\
1989 ; \\
\text { Gossens', Crain } \\
\text { i Edler, 1995 }\end{array}$} \\
\hline & $\begin{array}{l}\text { Tijekom interakcije komunikacijski partner pokazuje na } \\
\text { simbole u komunikacijskoj knjizi ili na pomagalu te pritom } \\
\text { govori. }\end{array}$ & \\
\hline & $\begin{array}{l}\text { Intervencija koja ima obilježje totalne komunikacije } \\
\text { (pristupa koji se razvija u okviru intervencija za osobe s } \\
\text { oštećenjem sluha). }\end{array}$ & \\
\hline & $\begin{array}{l}\text { Odabir simbola uvijek se prati njegovim značenjem } \\
\text { odnosno govornim modalitetom. }\end{array}$ & \\
\hline \multirow[t]{2}{*}{$\begin{array}{l}\text { Potpomognuti unos } \\
\text { (engl. augmented input) }\end{array}$} & $\begin{array}{l}\text { Intervencija koja ima primarni cilj podržati razvoj jezičnog } \\
\text { razumijevanja kroz kombinaciju vizualnog i auditivnog } \\
\text { unosa. }\end{array}$ & \multirow[t]{2}{*}{$\begin{array}{l}\text { Romski i Sevcik, } \\
1996\end{array}$} \\
\hline & $\begin{array}{l}\text { Ova intervencija dio je intervencije naziva Sustav za } \\
\text { obogaćivanje jezičnog unosa (engl. System for Augmenting } \\
\text { Language), koja se provodi u prirodnom okruženju s } \\
\text { komunikacijskim partnerima koji upotrebljavaju sredstva } \\
\text { PK te istodobno govore. }\end{array}$ & \\
\hline \multirow{3}{*}{$\begin{array}{l}\text { Prirodno obogaćeni } \\
\text { jezik } \\
\text { (engl. natural aided } \\
\text { language) }\end{array}$} & $\begin{array}{l}\text { Kombinacija obogaćenog jezičnog poticaja i prirodnih } \\
\text { strategija poučavanja iz Paradigme prirodnog jezika (engl. } \\
\text { Natural language paradigm). }\end{array}$ & \multirow[t]{3}{*}{ Cafiero, 2001} \\
\hline & $\begin{array}{l}\text { Intervencija se implementira u prirodnom okruženju } \\
\text { korištenjem komunikacijske ploče. }\end{array}$ & \\
\hline & $\begin{array}{l}\text { Istraživanja su pokazala pozitivne učinke za skupinu s } \\
\text { poremećajem iz spektra autizma. }\end{array}$ & \\
\hline \multirow{3}{*}{$\begin{array}{l}\text { Obogaćeno jezično } \\
\text { modeliranje } \\
\text { (engl. aided language } \\
\text { modeling) }\end{array}$} & $\begin{array}{l}\text { Uključuje pokazivanje na označeni predmet u okolini prije } \\
\text { pokazivanja na simbol na sredstvu PK. }\end{array}$ & \multirow{3}{*}{$\begin{array}{l}\text { Drager, Postal, } \\
\text { Carrolus, } \\
\text { Castellano, } \\
\text { Gagliano i } \\
\text { Glynn, } 2006\end{array}$} \\
\hline & $\begin{array}{l}\text { Koristi se s niskotehnološkim sredstvima PK u prirodnim } \\
\text { aktivnostima. }\end{array}$ & \\
\hline & $\begin{array}{l}\text { Preporučena učestalost - modelirati svaki cilj poučavanja } \\
4 \text { puta. }\end{array}$ & \\
\hline \multirow{3}{*}{$\begin{array}{l}\text { Obogaćeno } \\
\text { (potpomognuto) } \\
\text { modeliranje u PK } \\
\text { (engl. aided AAC } \\
\text { modeling) }\end{array}$} & $\begin{array}{l}\text { Uključuje prošireni govorni model slijedeći obogaćeno } \\
\text { modeliranje u PK. }\end{array}$ & \multirow[t]{3}{*}{$\begin{array}{l}\text { Binger i Light, } \\
2007\end{array}$} \\
\hline & Uključuje modeliranje dva simbola. & \\
\hline & $\begin{array}{l}\text { Određeno je doziranje (npr. minimalno } 30 \text { puta modelirati } \\
\text { PK sredstvo kroz } 15 \text { minuta). }\end{array}$ & \\
\hline \multirow{2}{*}{$\begin{array}{l}\text { Vizualni izranjajući } \\
\text { program } \\
\text { (engl. visual immersion } \\
\text { system) }\end{array}$} & $\begin{array}{l}\text { Komunikacijska kompetencija izgrađuje se uz vizualne } \\
\text { simbole. }\end{array}$ & \multirow[t]{2}{*}{$\begin{array}{l}\text { Shane i sur., } \\
2015\end{array}$} \\
\hline & $\begin{array}{l}\text { Uporaba vizualnih simbola u prirodnom okruženju } \\
\text { korisnika; naglasak na ulozi komunikacijskog partnera. }\end{array}$ & \\
\hline
\end{tabular}




\section{Učinkovitost intervencije jezičnog obogaćivanja u okviru potpomognute komunikacije}

\section{Učinkovitost obogaćenog jezičnog unosa za poticanje jezičnog razumijevanja $i$ proizvodnje}

Istraživanja obogaćenog jezičnog unosa usmjerena su na njegovu ulogu u jezičnom razvoju te potvrđuju kako obogaćeni jezični unos može biti promatran kao mehanizam koji unapređuje jezično razumijevanje osoba koje upotrbljavaju PK (Drager, 2009; Harris i Reichle, 2004) i modelira jezičnu ekspresiju (Binger, Kent-Walsh, Ewing i Taylor, 2010). U obogaćenom jezičnom unosu pokazivanje simbola na sredstvu PK prati i govorni dio. Govorni dio vrlo često komunikacijski partneri prezentiraju sporije i jednostavnije, jer on ovisi o lociranju i podudaranju sa simbolom na sredstvu PK, što može doprinijeti boljem jezičnom razumijevanju (Smith, 2015). Ipak, rijetka su istraživanja koja dokazuju učinkovitost ove intervencije na razumijevanje jezičnih sastavnica i simbola (Allen, Schlosser, Brock i Shane, 2017). Jedno takvo istraživanje je istraživanje autorica Dada i Alant (2009) koje potvrđuje da je obogaćenim jezičnim unosom moguće povećavanje rječnika kod djece s vrlo malo ili čak bez funkcionalnog govora. Djeca su u tom istraživanju postigla bolje razumijevanje 24 ciljane riječi, od kojih su tri bile imenice, a ostatak pridjevi. Jedno od objašnjenja zašto je takvih istraživanja malo je nemogućnost primjene standardiziranih testova jer oni često nisu prilagođeni za osobe sa složenim komunikacijskim potrebama (Light, 1997). Jezična proizvodnja očituje se kao rezultat, ponašanje koje se promatra (izgovorena riječ, aktiviranje simbola na govornom uređaju i sl.), a o razumijevanju jezika zaključuje se iz ponašanja koje je odgovor, reakcija na podražaj, zbog čega je mjerljivost učinkovitosti intervencije na jezično razumijevanje kod osoba koje upotrbljavaju PK znatno otežana.

\section{Učinkovitost obogaćenog jezičnog unosa u okviru poticanja različitih jezičnih sastavnica}

Sustavni pregled literature koja prikazuje rezultate učinka PK intervencija koje uključuju obogaćeni PK unos i metaanalize tih istraživanja upućuju na pozitivne učinke ove intervencije u poticanju pojedinih jezičnih sastavnica (Sennott i sur., 2016; O’Neill i sur., 2018). Ističe se kako ove intervencije imaju pozitivnu ulogu u poticanju pragmatičkog jezičnog razvoja ostvarivanjem napretka u jednom od najvažnijih ciljeva pragmatičkih jezičnih intervencija, a to je povećanje učestalosti komunikacijskih izmjena djece sa složenim komunikacijskim potrebama (Kent-Walsh, Binger i Hasham, 2010; Rosa-Lugo i Kent-Walsh, 2008). Rezultati istraživanja koja su se bavila ulogom ovih intervencija u poticanju semantičke jezične sastavnice upućuju na povećanje rječnika, iako najčešće malog broja ciljanih riječi, uglavnom imenica (Dada i Alant, 2009; Drager i sur., 2006; Harris i Reichle, 2004; Romski i sur., 2010). Jedno od malobrojnih istraživanja pokazuje učinke obogaćenog jezičnog unosa kod djece tipičnog razvoja u korištenju pridjeva i glagola, odnosno riječi koje izražavaju unutarnja stanja (Alviž, 2019).

PK intervencije koje uključuju modeliranje daju podršku i u generativnoj, fleksibilnoj i kombinatornoj uporabi jezika poticanjem slaganja riječi, odnosno kombiniranja simbola (Binger i Light, 2007; Binger i Light, 2008). Modeliranjem PK-a i PK preoblikovanjem potiče se i usvajanje morfoloških struktura jezika (Binger, Maguire-Marshall i Kent-Walsh, 2011). 
Popčević, K., Ivšac Pavliša, J., Bohaček, A., Obogaćeni jezični unos - intervencija u potpomognutoj komunikaciji, Klinička psihologija 13 (2020), 1-2, 79-94

Allen i sur. (2017) pregledom literature zaključuju kako intervencije obogaćenog unosa utječu na promjene u receptivnom i ekspresivnom rječniku, pragmatici i ekspresivnoj sintaksi te naglašavaju potrebu za provjeravanjem učinka izlaganja obogaćenom unosu na receptivne sintaktičke vještine, odnosno razumijevanje jezika na razini rečenice. Nedostaju također istraživanja naprednijih vještina na pragmatičkoj i leksičkoj sastavnici jezika (Sennot i sur., 2016).

\section{Učinkovitost obogaćenog jezičnog unosa u odnosu na obilježja ispitanika i sredstva PK}

Sudionici $\mathrm{u}$ istraživanjima koja provjeravaju učinkovitost obogaćenog jezičnog unosa u PK su djeca od 2 godine i 11 mjeseci do odraslih osoba kronološke dobi od 59 godina (Sennott i sur., 2016; O’Neill i sur., 2018). U većinu istraživanja uključena su djeca predškolske dobi (prosječne dobi 5 godina) (Sennott i sur., 2016) i rane školske dobi $(9,5$ godina) (O’Neill i sur., 2018). Pregledom 28 istraživanja (O’Neill i sur., 2018) ustanovljeno je da ova intervencijska tehnika nije toliko učinkovita za odrasle ispitanike (starije od 22 godine) kao i za ispitanike koji se nalaze u ranim stadijima usvajanja jezika (ispitanici koji su na razini jezičnog razumijevanja ispod 24 mjeseca) i komunikacije (ispitanici u predintencijskoj fazi komunikacije). Razloge autori nalaze u već naučenoj bespomoćnosti kod odraslih ispitanika, te prekratkom provođenju intervencije kod djece koja tek usvajaju komunikaciju. Teškoće ispitanika u spomenutim istraživanjima kreću se od cerebralne paralize, Downova sindroma, razvojnih teškoća, značajnih intelektualnih odstupanja do poremećaja iz spektra autizma. Istraživanja potvrđuju kako je ova intervencijska tehnika obećavajuća i kod djece s poremećajem iz spektra autizma (Cafiero, 1998; Acheson, 2006; Brady i sur.,
2015), što je zanimljiv podatak s obzirom na to da literatura često naglašava smanjenu sposobnost imitacije kod djece sa PSA-om (Toth, Munson, Meltzoff i Dawson, 2006) i njihovu veću usmjerenost na vizualni podražaj u odnosu na auditivni (Carr, Binkoff, Kologinsky i Eddy, 1978).

Pregledom literature obogaćenog jezičnog unosa u području PK uočava se da pojedini autori kao komunikacijska pomagala navode uređaje s govornim izlazom (Kent-Walsh i sur., 2010; Rosa-Lugo i Kent-Walsh, 2008), a pojedini autori druge vrste komunikacijskih pomagala (Solomon-Rice i Soto, 2014; Tönsing, 2016). Kod korištenja strategije obogaćenog jezičnog unosa s uređajem bez govornog izlaza, unos je dvostruk - komunikacijski partner pokazuje simbol i daje verbalni iskaz. Kod uređaja s govornim izlazom, unos je trostruk jer uz navedena dva unosa treći dolazi iz samog uređaja. Unatoč potvrđenoj preferenciji prema uređajima s govornim izlazom (O’Neil i sur., 2018) istraživanja pokazuju da i jedno i drugo sredstvo PK osigurava značajan pomak u komunikacijskim vještinama korisnika (Ganz, 2015; Tönsing, 2016; O’Neill i sur., 2018). Obogaćeni jezični unos u PK može biti prezentiran asinkrono (kada se simbol pokazuje prije ili nakon verbalnog iskaza) ili simultano (kada verbalni iskaz dolazi u isto vrijeme kada i pokazivanje simbola). Intervencije koje su upotrbljavale asinkroni model pokazale su se učinkovitijima (O’Neill i sur., 2018.) Razlog tome može biti što u sinkroniziranju simbola i govora komunikacijski partner svoj govor prilagođava simbolu na PK sredstvu, a to može rezultirati telegrafskim govorom. U asinkronom modelu govor više služi kao gramatički model. Također, osiguravanje dva unosa $\mathrm{u}$ isto vrijeme zahtijeva i podijeljenu pažnju kod korisnika PK, na komunikacijskog partnera i na uređaj, što za korisnika može biti dodatan izazov. 


\section{KLINIČKE PREPORUKE}

Dosadašnja istraživanja podržavaju preporuke o uporabi obogaćenog PK unosa s ciljem osnaživanja širokog raspona komunikacijskih i jezičnih vještina kod osoba koje upotrebljavaju PK. Međutim, istraživanja se razlikuju u odrednicama o načinu provedbe ove intervencije zbog čega je trenutačno otežano izdvojiti precizne i univerzalne smjernice za njezinu implementaciju. Iz tog razloga ovdje se izdvajaju neke od njih koje istraživanja podupiru kao učinkovite.

O’Neill i sur. (2018) na temelju metaanalize navode kako ove intervencije mogu biti učinkovite u relativno kratkom periodu (nakon 5 sati intervencije) ako se implementiraju od strane komunikacijskih partnera u svakodnevnim prirodnim okruženjima. Nadalje, utvrđuju kako obogaćeni PK unos postiže učinkovitost kao zasebna intervencijska strategija ili u kombinaciji s drugim intervencijskim komponentama kao što su iščekujuće stanke, proširenja, nadovezujući odgovori (engl. contingent responses) i preoblikovanja.

Poučavanje komunikacijskih partnera kako pružati obogaćeni PK unos ističe se kao ključno jer oni imaju značajan utjecaj na učinak ove intervencije. Preporuča im se da pokazivanje na grafičke simbole povezuju s gramatički ispravno izgovorenim rečenicama (Bohaček i Pećnik, 2019). Obogaćeni unos može uključivati jednu ili dvije ključne riječi ili cijelu frazu (O’Neill i sur., 2018). Preporučuje se učestalost modeliranja više od jednom u minuti (O’Neill i sur., 2018) te modeliranje ciljane riječi/simbola četiri puta tijekom petnaestominutne aktivnosti igre s djetetom (Drager i sur., 2006). Vremenski razmak između povezivanja simbola $\mathrm{u}$ iskaze te između pokazivanja na simbol i referent ne bi trebao biti veći od dvije sekunde (Drager i sur., 2006).
Gossens', Crain i Edler (1995) razvile su cijeli koncept poučavanja PK u manjim skupinama imajući u vidu prilagodbu okoline na način da je omogućeno neposredno modeliranje PK simbola, stvaranje komunikacijskih prilika dajući korisnicima "bogati rječnik" u PK sustavima, modeliranje PK kroz svakodnevne rutine te poticanje korisnika da prilikom izražavanja upotrebljavaju simbole. Pri tome se preporučuju sljedeći koraci koji se smatraju univerzalnima, zagovaraju se u većini spomenutih radova te su danas dio suvremene kliničke prakse u kojoj se koristi PK (Goossens', 1989; Sennot i sur., 2016; Hartmann, 2019):

1. Jezični unos treba imati više komentara nego pitanja (odnos izjavnih rečenica/komentara - pitanja je $80: 20$ ). Na taj se način osigurava veći unos, a manje naglašava jezična proizvodnja kod djeteta.

2. Obogaćeni jezični unos (govorni dio uz pokazivanje na PK sredstvu) valja osigurati $70 \%$ vremena. Navedeno podrazumijeva da odrasla osoba tijekom svog obraćanja djetetu $70 \%$ vremena istodobno pokazuje simbole.

\section{OGRANIČENJA}

Pregledi istraživanja intervencija koje uključuju modeliranje PK-a dosljedno izvještavaju o pozitivnim učincima poput smanjenja asimetrije unosa i izlaza, jačanja jezičnog razumijevanja i proizvodnje, unaprjeđenja komunikacijskih vještina i cjelokupne kvalitete života osoba sa složenim komunikacijskim potrebama povezanih s različitim dijagnozama, jezičnim vještinama i različitom dobi (O’Neill i sur., 2018). S druge strane, ističu se i određena ograničenja tih istraživanja te potreba za daljnjim istraživanjima.

Ograničenja zaključaka postojećih istraživanja proizlaze iz razlika među pojedinim 
Popčević, K., Ivšac Pavliša, J., Bohaček, A., Obogaćeni jezični unos - intervencija u potpomognutoj komunikaciji, Klinička psihologija 13 (2020), 1-2, 79-94

istraživanjima u načinu pružanja ove vrste intervencije, primjerice razlika u učestalosti i trajanju intervencija, učestalosti modeliranja tijekom terapijskog sata, obilježjima obogaćenog jezičnog unosa (mjeri poklapanja govora i pokazivanja simbola, simbolima koji su dostupni u komunikacijskom pomagalu) i kontekstu (prirodno okruženje u odnosu na kliničko). Ističe se nedostatak podataka o održavanju i generalizaciji. Postojeća istraživanja uglavnom se temelje na istraživačkim nacrtima na pojedincu, dok su grupni nacrti u području PK-a vrlo rijetki.

Ograničenja se zamjećuju u nedostatku podataka o učinku obogaćenog PK unosa kod pojedinih profila sudionika u odnosu na dobni raspon (kod adolescenata i odraslih), teškoće (kod osoba sa složenim motoričkim teškoćama, kod osoba s niskom razinom jezičnog razumijevanja), na ciljeve (utjecaj na razumijevanje, posebice razumijevanje morfosintakse te na složenije jezične vještine) i na obilježja intervencije (utjecaj obogaćenog PK unosa kao izolirane nezavisne varijable u odnosu na obogaćeni PK unos kao strategije u okviru višekomponentne intervencije) (O’Neill i sur., 2018; Sennott i sur., 2016). Potrebna su i istraživanja koja će se usmjeriti na profile sudionika kod kojih ova vrsta intervencije ne postiže učinak. Nepoznato je utječu li pojedini aspekti profila korisnika PK-a, poput njihove jezične razine, intelektualnog funkcioniranja, sposobnosti brzog mapiranja i združene pažnje na postizanje učinka PK intervencija koje se temelje na modeliranju (Sennott i sur., 2016).

Zbog navedenih ograničenja, naglašava se potreba za daljnjim istraživanjima ove vrste intervencije kako bi se uz znanstveno utemeljene dokaze mogla smatrati znanstveno potvrđenom (Popčević, Ivšac Pavliša, Šimleša i Bašić, 2016).

\section{ZAKLJUČNO RAZMATRANJE}

Dosadašnja istraživanja pokazuju brojne pozitivne utjecaje obogaćenog jezičnog unosa na komunikacijska i jezična obilježja korisnika potpomognute komunikacije: napredak u komunikacijskim vještinama djece koja počinju komunicirati uz PK (Sennott i sur., 2016), napredak u jezičnom razumijevanju (Dada i Alant, 2009), napredak u simboličkom razumijevanju i jezičnoj proizvodnji - povećava duljinu i složenost jezičnih iskaza (Drager i sur., 2006; Harris i Reichle, 2004). Primjena ove strategije ujedno osigurava korisnicima model uporabe potpomognute komunikacije u različitim kontekstima, responzivnost $\mathrm{u}$ komunikaciji i učinkovitost uporabe različitih komunikacijskih sustava (Cafiero, 2001; Ivšac Pavliša, Feješ, Car, Vuković i Mandić, 2014).

Pregledom literature o obogaćenom jezičnom unosu u PK zamjećuje se kako je terminologija nedosljedna, susreću se različiti nazivi koji opisuju istu ili vrlo sličnu intervencijsku tehniku. Učinkovitost ove intervencije istražuje se u kliničkim i u prirodnim uvjetima s različitim dobnim, razvojnim i jezičnim karakteristikama ispitanika, što utječe na veliku različitost u metodološkim pristupima. Različiti su i ciljevi poučavanja ovom tehnikom. Ponekad se želi povećati razumijevanje grafičkih simbola, obogatiti jezičnu proizvodnju, povećati broj zahtijevanja simbolima ili naučiti korisnika multimodalnim iskazima tijekom interakcije. Međutim, unatoč ovoj različitosti, zaključci svih istraživanja imaju istu nit - modeliranje uz obogaćeni jezični unos jedan je od ključnih elemenata implementacije potpomognute komunikacije. Na temelju svega navedenog zaključuje se da modeliranje koje je tradicionalno učestalo korištena strategija u kliničkom radu logopeda valja nadograditi strategijom obogaćenog jezičnog unosa u indi- 
vidualnom i skupnom radu s korisnicima potpomognute komunikacije (Cheslock, Romski, Sevcik i Adamson, 2002; Ivšac Pavliša, Peretić, Bohaček i Talian, 2016).

\section{LITERATURA}

Acheson, M. J. (2006). The effect of Natural Aided Language Stimulation on Requesting Desired Objects or Actions in Children with Autism Spectrum Disorder. University of Cincinnati, Division of Graduate Eduacation and Research, Department of Special Education.

Allen, A. A., Schlosser, R. W., Brock, K. L. i Shane, H. C. (2017). The effectiveness of aided augmented input techniques for persons with developmental disabilities: a systematic review. Augmentative and Alternative Communication, 33, 149-159. DOI: 10.1080/07434618.2017.1338752

Alviž, S. (2019). Učinkovitost primjene adaptiranih slikounica za poticanje jezičnih sposobnosti. Zagreb: Edukacijsko-rehabilitacijski fakultet.

Bavelier, D., Newport, E. L. i Supalla, T. (2003). Children need natural languages, signed or spoken. Cerebrum, 5, 19-32.

Beukelman, D. i Garrett, K. (1988). Augmentative and alternative commuication for adults with acquired severe communication disorders. $A u$ gmentative and Alternative Communication, 4, 104-121.

Beukelman, D. i Mirenda, P. (2013). Augmentative and alternative communication: Supporting children and adults with complex communication needs (4 izd.). Baltimore, MD: Brookes.

Binger, C. i Light, J. (2007). The effect of aided AAC modeling on the expression of multi-symbolmessages by preschoolers who use AAC. Augmentative and Alternative Communication, 23, 3043. DOI: $10.1080 / 07434610600807470$

Binger, C. i Light, J. (2008). The morphology and syntax of individuals who use AAC: Research review and implications for effective practice. Augmentative and Alternative Communication, 24, 123-138. DOI: $10.1080 / 07434610701830587$
Binger, C., Kent-Walsh, J., Ewing, C. i Taylor, S. (2010). Teaching educational assistants to facilitate the multisymbol message productions of young students who require augmentative and alternative communication. American Journal of Speech-Language Pathology, 19, 108-120. DOI: 10.1044/ 1058-0360

Binger, C., Maguire-Marshall, M. i Kent-Walsh, J. (2011). Using aided AAC models, recasts, and contrastive targets to teach grammatical morphemes to children who use AAC. Journal of Speech, Language, and Hearing Research, 54, 160-176. DOI: 10.1044/1092-4388(2010/090163)

Blockberger, S. i Sutton, A. (2003). Toward linguistic competence: Language experiences and knowledge of children with extremely limited speech. U J. Light, D. Beukelman i J. Reichle (ur.), Communicative competence for individuals who use AAC: From research to effective practice (str. 63-106). Baltimore, MD: Brookes.

Bohaček, A. (2020). Važnost ranih interakcija. Drugi županijski simpozij o ranoj intervenciji u djetinjstvu, Pula.

Bohaček, A. i Pećnik, N. (2019). Učinkovitost programa podrške roditeljima djece s PSA u odnosu na roditelje djece $\mathrm{s}$ drugim teškoćama $\mathrm{u}$ razvoju. Peti hrvatski simpoziji o ranoj intervenciji, Split.

Brady, N. C., Storkel, H. L., Bushnell, P., Barker, M. R., Saunders, K., Daniels, D. i Fleming, K. (2015). Investigating a Multimodal Intervention for Children With Limited Expressive Vocabularies Associated With Autism. American Jorunal of Speech - Language Pathology, 24, 438-459.

Bruner, J. (1983). Child's talk. Oxford: Oxford University Press.

Burkhart, L. J. (2019). What is AAC? International Society for Augmentative and Alternative Communication. (2019, kolovoz 21). Preuzeto s https://www.isaac-online.org/english/ what-is-aac/

Cafiero, J. (1998). Communication Power for Individuals with Autism. Focus on autism and other developmental disabilities, 13(2), 113-121.

Cafiero, J. M. (2001). The effect of an augmentative communication intervention on the 
Popčević, K., Ivšac Pavliša, J., Bohaček, A., Obogaćeni jezični unos - intervencija u potpomognutoj komunikaciji, Klinička psihologija 13 (2020), 1-2, 79-94

communication, behavior, and academic program of an adolescent with autism. Focus on Autism and Other Developmental Disabilities, 16, 179-189.

Calculator, S. (1997). Fostering early language acquisition and AAC use: Exploring reciprocal influences between children and their environments. Augmentative and Alternative Communication, 13, 149-157. DOI: 10.1080/07434619712331277968

Carr, E. G., Binkoff, J. A., Kologinsky, E. i Eddy, M. (1978). Acquisition of sign language by autistic children. Expressive labelling. Journal of Applied Behavior Analysis, 11, 489-501. DOI: 10.1901/jaba.1978.11-489

Cheslock, M., Romski, M. A., Sevcik, R. A. i Adamson, L. B. (2001). Augmented Language Intervention Project: From School-Aged Youth to Toddlers. Perspectives on Language Learning and Education, 1, 18-23.

Dada, S. i Alant, E. (2009). The Effect of Aided Language Stimulation on Vocabulary Acquisition in Children With Little or No Functional Speech. American Jorunal of Speech - Language Pathology, 18, 50-64.

Drager, K. D. R. (2009). Aided Modeling Interventions for Children With Autism Spectrum Disorders Who Require AAC. Perspectives on Augmentative and Alternative Communication, 18(4), 114-120. DOI: 10.1044/aac18.4.114

Drager, K. D., Postal, V. J., Carrolus, L., Castellano, M., Gagliano, C. i Glynn, J. (2006). The effect of aided language modeling on symbol comprehension and production in 2 preschoolers with autism. American Journal of Speech-Language Pathology, 15, 112-125. DOI: 10.1044/ 1058-0360

Gallway, C. i Richards, B. J. (1994). Input and interaction in language acquisition. Cambridge. UK: Cambridge University Press.

Ganz, J. B. (2015). AAC Interventions for Individuals with Autism Spectrum Disorders: State of the Science and Future Research Directions. Augmentative and Alternative Communication, 31(3), 203-214.

Gerken, L. A. (2008). Language development. San Diego, CA: Plural Publishing.

Goossens', C. (1989). Aided Communication Intervention Before Assessment: A Case Study of a Child with Cerebral Palsy. Augmentative and Alternative Communication, 5(1), 14-26.

Goossens', C., Crain, S. i Elder, P. (1995) Engineering the Preschool environment for interactive, symbolic communication: An emphasis on the developmental period 18 months to five years. Birmingham: Southeast Augmentative Communication Publications.

Harris, M. D. i Reichle, J. (2004). The Impact of Aided Language Stimulation on Symbol Comprehension and Production in Children With Moderate Cognitive Disabilities. American Journal of Speech-Language Pathology, 13(2), 155-167. DOI: 10.1044/10580360(2004/016)

Hart, B. i Risley, T. R. (1995). Meaningful differences in the everyday experience of young American children. Baltimore, MD: Brookes.

Hartmann, A. (2019). AAC Tools and Strategies. U M. Šimanović (Ur). Kniiga sažetaka, Peti hrvatski simpozij o ranoj intervenciji u djetinjstvu: Rano otkrivanje, dijagnostika i podrška kod poremećaja iz spektra autizma (str. 17). Zagreb: Hrvatska udruga za ranu intervenciju u djetinjstvu - HURID.

Huttenlocher, J., Haight, W., Bryk, A., Seltzer, M. i Lyons, T. (1991). Early vocabulary growth: Relation to language input and gender. Developmental Psychology, 27, 236-238.

Ivšac Pavliša, J., Popčević, K. i Rosandić, M. (2019). Je li važno kako se intervencija zove ili koliko je učinkovita? Peti hrvatski simpozij o ranoj intervenciji u djetinjstvu: Rano otkrivanje, dijagnostika i podrška kod poremećaja iz spektra autizma, Split.

Ivšac Pavliša, J., Feješ, A., Car, Ž., Vuković, M. i Mandić, L. (2014). User Experiences from Croatian ICT Competence Network for Innovative Services for Persons with Complex Communication Needs. Discover Communication, ISAAC, Canada.

Ivšac Pavliša, J., Peretić, M., Bohaček, A. i Talian, K. (2016). IKT u vrtiću - od istraživanja do primjene. Dijete, vrtić, obitelj : časopis za odgoj $i$ naobrazbu predškolske djece namijenjen stručnjacima i roditeljima, 80/81, 16-20.

Ivšac Pavliša, J., Ljubešić, M. i Jerečić, I. (2012). The use of AAC with young children in Croatia-from the speech and language pathologist's view. U G. Jezic i sur. (Ur.), Agent and Multi- 
Popčević, K., Ivšac Pavliša, J., Bohaček, A., Obogaćeni jezični unos - intervencija u potpomognutoj komunikaciji, Klinička psihologija 13 (2020), 1-2, 79-94

Agent Systems: Technology and Applications' Proceedings of the 6th International Conference (221-230). Berlin, Heidelberg: Springer Verlag.

Kent-Walsh, J., Binger, C. i Hasham, Z. (2010). Effects of parent instruction on the symbolic communication of children using augmentative and alternative communication during storybook reading. American Journal of Speech-Language Pathology, 19, 97-107. DOI: 10.1044/1058-0360(2010/09-0014)

Kuhar, I., Prizl Jakovac, T. i Ivšac Pavliša, J. (2016). Primjena informacijsko-komunikacijske tehnologije u logopedskom radu u osoba s afazijom - prikaz dva slučaja. Hrvatska revija za rehabilitacijska istraživanja, 52(2), 104-115.

Light, J. (1997). "Let's go star fishing”: Reflections on the contexts of language learning for children who use aided AAC. Augmentative and Alternative Communication, 1, 74-83. DOI: 10.1080/07434619712331277978

O’Neill, T., Light, J. i Pope, A. (2018). Effects of interventions that include aided augmentative and alternative communication input on the communication of individuals with complex communication needs: A meta-analysis. Journal of Speech, Language, and Hearing Research, 61, 1743-1765. DOI: 10.1044/2018_ JSLHR-L-17-0132

Pampoulou, E. (2017). Graphic symbols terminology: A call for a consensus. Journal of Enabling Technologies, 11, 92-100. DOI: 10.1108/JET02-2017-0008

Popčević, K., Ivšac Pavliša, J. i Šimleša, S. (2014). Ishodi djece s poremećajima iz autističnog spektra nakon razvojne procjene. Klinička psihologija, 8, 1-14.

Popčević, K., Ivšac Pavliša, J., Bohaček, A., Šimleša, S. i Bašić, B. (2016). Znanstveno utemeljene intervencije kod poremećaja iz spektra autizma. Hrvatska revija za rehabilitacijska istraživanja, 52, 100-113.

Rašan, I., Slivar, I., Žilak, M., Car, Ž. i Ivšac Pavliša, J. (2019). ICT-AAC aplikacije kao medij za komunikaciju i učenje. Zbornik radova: Računalne igre 2019 (51-59). Zagreb: Fakultet organizacije i informatike.

Romski, M. A. i Sevcik, R. A. (1988). Augmentative communication system acquisition and use:
A model for teaching and assessing progress. NSSLHA Journal, 15, 61-75.

Romski, M. A. i Sevcik, R. A. (1996). Breaking the speech barrier: Language development through augmented means. Baltimore, MD: Brookes.

Romski, M. A., Sevcik, R. A., Adamson, L. B., Cheslock, M., Smith, A., Barker, R.M. i Bakeman, R. (2010). Randomized comparison of augmented and nonaugmented language interventions for toddlers with developmental delays and their parents. Journal of Speech, Language, and Hearing Research, 53, 350-364.

Rosa-Lugo, L. I. i Kent-Walsh, J. (2008). Effects of parent instruction on communicative turns of Latino children using augmentative and alternative communication during storybook reading. Communication Disorders Quarterly, 30, 49-61. DOI: 10.1177/1525740108320353

Sennott, S. C., Light, J. C. i McNaughton, D. (2016). AAC Modeling Intervention Research Review. Research and Practice for Personswith Severe Disabilities, 41, 101-115. DOI: $10.1177 / 1540796916638822$

Sevcik, R. A. i Romski, M. A. (2002). The role of language comprehension in establishing early augmented conversations. U J. Reichle, D. Beukelman, J. Light (Ur.), Implementing an augmentative communication system: Exemplary strategies for beginning communicators (453-474). Baltimore, MD: Brookes.

Sevick, R. A., Romski, M. A., Watkins, R. V. i Deffebach. K. P. (1995). Adult Partner - Augmented Communication Input to Youth With Mental Retrdadion Using the System for Augmenting Language (SAL). Journal of Speech and Hearing Research, 38, 902-921.

Shane, H. C., Laubscher, E., Schlosser, R. W., Fadie, H. L., Sorce, J. F., Abramson, J. S., Flynn, S. i Corley, K. (2015). Enhancing Communication for Individuals with Autism. A Guide to the Visual Immersion System. Baltimore: BrookesPublishing.

Smith, M. i Grove, N. (2003). Asymmetry in input and output for individuals who use augmentative and alternative communication. U J. Light, D. Beukelman i J. Reichle (Ur.). Communicative competence of individuals who use augmentative and alternative communication (163195). Baltimore, MD: Brookes. 
Popčević, K., Ivšac Pavliša, J., Bohaček, A., Obogaćeni jezični unos - intervencija u potpomognutoj komunikaciji, Klinička psihologija 13 (2020), 1-2, 79-94

Smith, M. M. (2015). Language development of individuals who require aided communication: Reflections on state of the science and future research directions. Augmentative and Alternative Communication, 31, 215-233. DOI: 10.3109/ 07434618.2015.1062553

Solomon-Rice, P. L. i Soto, G. (2014). Facilitating Vocabulary in Toddlers Using A-AC. Communication Disorders Quarterly, 35, 204-215. DOI: $10.1177 / 1525740114522856$

Tannock, R. i Girolametto, L. (1992). Reassessing parent-focused language intervention programs. U S. F. Warren i J. E. Reichle (Ur.), Communication and language intervention series, Vol. 1. Causes and effects in communication and language intervention (49-79). Baltimore, MD, England: Paul H. Brookes Publishing.

Tomasello, M. (2003). Constructing a language. Cambridge, MA: Harvard University Press.

Tönsing, M. (2016). Supporting the Production of Graphic Symbol Combinations by Children with Limited Speech: A Comparison of Two AAC systems. Journal of Develppmental and Physical Disabilities, 28, 5-29.
Toth, K., Munson, J., Meltzoff, A. N. i Dawson, G. (2006). Early predictors of communication development in young children with autism spectrum disorder: Joint attention, imitation, and toy play. Journal of Autism and Developmental Disorders, 36, 993-1005. DOI: 10.1007/s10803-006-0137-7

von Tetzchner, S. (2018). Introduction to the special issue on aided language processes, development, and use: an international perspective. Augmentative and Alternative Communication, 34, 1-15. DOI: 10.1080/07434618.2017.1422020

von Tetzchner, S. i Martinsen, H. (2000). Introduction to augmentative and alternative communication (2. izd.). London: Whurr/Wiley.

Vygotsky, L. (1962). Thought and language. Cambridge, MA: MIT Press.

Wood, L., Lasker, J., Siegel-Causey, E., Beukelman, D. i Ball, L. (1998). Input framework for augmentative and alternative communication. Augmentative and Alternative Communication, 14(4) 261-267. DOI: $10.1080 / 07434619812331278436$

$\begin{array}{ll}\text { Primljeno: } & \text { 05. 02. } 2020 . \\ \text { Prihvaćeno: } & \text { 24. 09. } 2020 . \\ \text { Online: } & \text { 30.10.2020. } \\ \text { Print: } & \text { 27.11.2020. }\end{array}$

Korespondencija: Klara Popčević

Edukacijsko-rehabilitacijski fakultet Sveučilišta u Zagrebu, Borongajska 83 f, 10000 Zagreb

klara.popcevic@erf.unizg.hr

\section{Augmented Language Input - Intervention Within Augmentative and Alternative Communication Based on Modelling}

Summary: The field of interventions developed within the context of Augmentative and Alternative Communication (AAC) that use modelling as a core strategy is a relatively young research area. This area has been developing more intensely in recent years. Despite numerous evidence that the strategy of modelling aided language input is effective for language development, modelling is traditionally connected to modelling gestures, manual signs or speech, but not as a strategy of modelling using graphic symbols, manual signs, communicative boards, books or specialized devices. AAC modelling interventions are focused on encouraging language abilities of children/users of AAC. This paper will argue about the theoretical source of aided language input that presents the type of "receptive language training" with a communicative partner as a key person who speaks and shows the symbols at the same time. The aided language input generates 
form constructive and social interactionist theories of language development. In its performance, it depicts the way children usually acquire language. The literature review shows that there is numerous evidence on the effectiveness of augmented language input in the field of communication and language development (Dada, Alant, 2009; Drager, 2009; Sennott, Light, Mc Naughton, 2016). This review presents key data about the concept of aided language input, changes in terminology, research findings and clinical recommendations, all with the goal of promoting this concept in the research and clinical field.

Key words: modelling, aided language, communicative partner, receptive training, augmentative and alternative communication 